\title{
Research of the Effect of Hyperthyroidism on Reaction Time Using the Oddball Paradigm
}

\author{
Hipertiroidilerde Reaksiyon Zamanının Oddball Paradigması ile Araștıııması
}

\author{
Nazan Dolu', Seval Keloğlan Müsüroğlu², Leyla Șahin ${ }^{3}$, Kürșad Ünlühizarci', Mustafa Tayfun Turan ${ }^{5}$ \\ ${ }^{1}$ Erciyes University Faculty of Medicine, Department of Physiology, Kayseri; ${ }^{2}$ Amasya University School of Health, Department of Nursing, \\ Amasya; ${ }^{3}$ Mersin University Faculty of Medicine, Department of Physiology, Mersin; ${ }^{4}$ Erciyes University Faculty of Medicine, Department \\ of Endocrinology, Kayseri; ${ }^{5}$ Erciyes University Faculty of Medicine, Department of Mental Health and Disease, Kayseri, Turkey
}

\begin{abstract}
Aim: Thyroid hormones are so important for the normal physiological functions and the cognitive functions of brain. It is known that hyperthyroidism, the presence of excessive thyroid hormone produced by the thyroid gland, causes changes in cognitive functions. In this study, we have examined the effect of hyperthyroidism on motor response that result from this cognitive process by measuring reaction time to auditory stimuli.
\end{abstract}

Material and Method: The study was conducted on newly diagnosed hyperthyroid patients $(n=20)$ and healthy controls $(n=20)$. The reaction time was evaluated in an auditory oddball paradigm. For that purpose, participants have been listened to 160 sound stimuli (120 standards, 40 targets). We asked them to press the button under their right hand when they hear the target sounds. The elapsed time between the presentation of the stimulus and the subsequent pressing button has been defined as reaction time.

Results: Reaction time was significantly prolonged in the hyperthyroid group compared with the control group ( $p \leq 0.001)$.

Conclusion: Hyperthyroid patients had prolonged perception time and significant decrease on attention and concentration. They can be result in prolonged reaction time because of impaired motor functions.

Key words: hyperthyroidism; Oddball paradigm; reaction time; human; cognition

\section{ÖZET}

Amaç: Tiroid hormonları beyinde fizyolojik ve bilișsel ișlevler için oldukça önemlidir. Tiroid bezinden așırı tiroid hormonu üretimi ile karakterize olan hipertiroidizmin bilișsel ișlevlerde değișikliklere neden olduğu bilinmektedir. Bu çalıșmada, ișitsel uyaranlara reaksiyon zamanı ölçülerek hipertiroidi'nin bilișsel süreçten kaynaklanan motor yanıt üzerine etkisi araștırıldı.

Seval Keloğlan Müsüroğlu, Sağlık Yüksekokulu / İpekköy Yerleskesi 05000 Amasya Türkiye, Tel.03582181767/4644Email.sevallkeloglan@hotmail.com Geliş Taribi: 04.04.2017 • Kabul Taribi: 06.11.2017
Materyal ve Metot: Çalıșma, yeni tanı konmuș hipertiroidi hastaları $(n=20)$ ve sağlıklı kontrol grubu $(n=20)$ üzerinde yürütüldü. Tepki süresi ișitsel oddball paradigması ile değerledirildi. Bu amaçla katıımcılara 160 ses uyaranı verildi (120 standart, 40 hedef). Katıımcılara ses uyaranını duyduklarında sağ ellerinin altındaki butona basmaları istendi. Uyaranın verilmesi ve butona basma süresi arasında geçen süre reaksiyon zamanı olarak hesaplandı.

Bulgular: Reaksiyon zamanı anlamlı șekilde hipertiroidi grubunda kontrol grubuna göre uzadı $(p \leq 0,001)$.

Sonuç: Hipertiroidili hastalarının algılama süreleri uzamakta, dikkat ve konsantrasyonda anlamlı azalma olmuștur. Bu duruma bozulmuș motor fonksiyondan kaynaklanan uzamıș reaksiyon zamanı neden olmuș olabilir.

Anahtar kelimeler: reaksiyon zamanı; Oddball paradigmasl; hipertiroidi; insan; biliș

\section{Introduction}

Thyroid hormones are critical regulatory molecules which are quite important for the mammal physiology with their functions such as the development of fetal and post-natal nervous system, the maintenance of adult brain functions, as well as the development and organ functions ${ }^{1}$. In addition to memory, cognitive and motor functions; thyroid hormones are closely related with numerous pathophysiologic conditions such as subfertility, mood disorders, depression and demen$\mathrm{tia}^{2,3}$. Although there are numerous studies examining the effects of thyroid hormones on cognitive dysfunction and psychiatric symptoms, the primary processes underlying these disorder have not exactly been clarified yet ${ }^{4,5}$. These primary processes probably appear as a complex result of the effects of thyroid dysfunction on the cellular metabolic processes and its primary and secondary effects on the neural networks ${ }^{6}$. 
Hyperthyroidism is an illness diagnosed with clinically decreased amount of thyroid stimulating hormone (TSH) and/or increased serum triiodothyronine (T3) and thyroxine (T4) levels ${ }^{7}$. Low or high TSH concentrations (within the reference range) and low cognitive performance have been associated ${ }^{8,9}$. Hyperthyroid causes increased resting energy consumption, loss of weight, decreased cholesterol levels, increased lipolysis, and development of hypermetabolic conditions characterized by gluconeogenesis ${ }^{10,11}$. The studies have revealed that hyperthyroidism leads to cognitive dysfunctions, the development of bipolar disordersand changes in brain size ${ }^{12,13}$. The studies have also indicated that excessive thyroxine causes the oxidative stress and damage on neurons ${ }^{14}$. Among the patients with Graves, which is a type of hyperthyroidism illness, cognitive disorders have been observed in the toxic phase of thyrotoxicosis, but no cognitive disorders have been found in the neuropsychological tests ${ }^{15}$. Wijsmanet al., determined no correlation regarding cognitive dysfunction among the elderly patients having hypo or hyperthyroid with no clinical characteristics ${ }^{16}$.

In the studies, it was seen that the temporary profound hypothyroidwas characterized by reversible depressionand it caused fine motor performance, reaction time and process rate to decrease ${ }^{17}$ Therefore, the aim of this study was to measure the reaction time in hyperthyroid patients and to investigate on whether they causedysfunction in cognitive and motor functions through oddball paradigm.

\section{Material and Method}

\section{Patient Selection}

The study was performed in the Electrophysiology Laboratory of the Department of Physiology, , Faculty of Medicine in Erciyes University. Patients having hyperthyroid disease were randomly enrolled in the study protocol. Randomization was carried by enrolling patients consecutively as they were referred to the endocrinology clinic at Erciyes University Hospital. Age and sex matched volunteers were taken as controls. The control group was healthy volunteers without no clinical evidence of thyroid dysfunction. The study was conducted on 20 newly diagnosed hyperthyroid female and male patients with mean age of $39.6 \pm 1.8$ years and 20 healthyindividuals as control group with mean age of $42.2 \pm 2.0$ years. The hyperthyroid patients were diagnosed with general history, clinical examination and serum levels of $\mathrm{fT} 3, \mathrm{fT} 4$ and TSH. The patients were belonged to middle socioeconomic status. Intelligence was not evaluated in this study, but all participants had completed high school. They also had hyperthyroid symptoms. The average interval between the diagnosis and start of symptoms was about 6-12 months. The subjects were categorized into 2 groups: group $\mathrm{I}=$ healthy controls; group II=hyperthyroid patients. All participants of the study gave informed consent to participate in accordance with the Helsinki declaration. All experiments were performed according to the guidelines of the Erciyes University Ethics Committee (08/236). Subjects suffering from any hearing impairment, systemic disease or any history of drug abuse (nicotine, alcohol, opium etc.) and pregnant women were excluded from the study.

\section{Determination of Reaction Time}

The reaction time was evaluated in an auditory oddball paradigm. For that purpose, participants have been listened to 160 sound stimuli (120 standards, 40 targets). We asked them to press the button under their right hand when they heard the target sounds. The elapsed time between the presentation of the stimulus and the subsequent pressing button has been defined as reaction time.

Correct response times to target stimuli were calculated Standard $(2000 \mathrm{~Hz})$ and target $(1500 \mathrm{~Hz})$ auditory stimuli were presented binaurally over headphones to the subject with duration of $1000 \mathrm{msec}$. The target tone occurred regularly with a 0.20 probability. The rise and fall time of each tone was $5 \mathrm{msec}^{18}$.

The obtained data was analyzed byusing SPSS software (version 13.0). The data is expressed as mean \pm standard derivation (SD). The statistical analysis for the comparison between control group and hyperthyroid patients for the thyroid hormon eweredone using ANOVA and reaction time Mann Whitney $U$. Differences were considered significant when $p<0.05$.

\section{Results}

Presence of a neurological or psychiatric disorder (especially, the taking of neuropsychiatric medications), another metabolic and endocrine disorder, malignity and pregnancy were determined as the exclusion criteria for all participants (especially, the taking of neuropsychiatric medications). No statistically significant difference was found on the comparison of groups based on age $(\mathrm{p}>0.05)$. On the other hand, in the comparison of hormone values, serum sT 3 and sT 4 levels of hyperthyroid patients were found to be higher than the control group $(\mathrm{p}=0.001)$. In patients with hyperthyroid and 


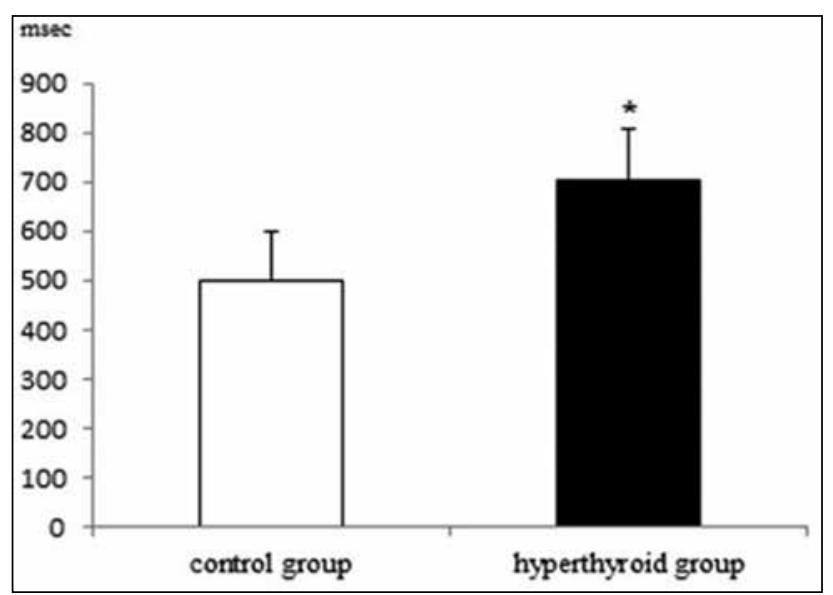

Figure 1. Comparison of reaction time determined by oddball paradigm between groups.

control groups, the hormone levels were respectively4.38 \pm 0.2 and $3.13 \pm 0.07 ;(\mathrm{F}=14.79)$ for $\mathrm{sT} 3(\mathrm{pg} / \mathrm{ml})$, and 16.49 \pm 1.0 and $8.19 \pm 0.21 ;(\mathrm{F}=43.75)$ for $s \mathrm{~T} 4(\mathrm{pg} /$ $\mathrm{ml})$. The TSH $(\mu \mathrm{u} / \mathrm{ml})$ hormone was found as $0.05 \pm 0.2$ among the hyperthyroid group, and 2.6 $\pm 0.1(\mathrm{~F}=111.01$, $\mathrm{p}=0.001)$ in the control group. The normal levels of hormones were taken as: $\mathrm{sT}_{3}: 2.5-3.9 \mathrm{pg} / \mathrm{ml} \mathrm{sT}_{4}: 6.1-11.2$ $\mathrm{pg} / \mathrm{ml}$, and TSH: $0.35-5.5 \mu \mathrm{u} / \mathrm{ml}$, while the reaction time determined by oddball paradigm in the present study was significantly $(\mathrm{z}=-4.46, \mathrm{p} \leq 0.001)$ prolonged in the hyperthyroid group $(704.06 \pm 104.37)$ compared to the control group $(500.27 \pm 100.92)$ (Fig. 1).

\section{Discussion}

Thyroid hormone plays an important role in the cognitive disorders and it is obviously detected among mood disorders, neuropsychiatric disorders, and thyroid patients ${ }^{4}$. Additionally, cognitive functions are a complex processes with many determinants which are not only associated with the thyroid function ${ }^{19}$. In this study, we have examined the effect of hyperthyroidism on motor response that results from this cognitive process by measuring the reaction time to auditory stimuli.

Previous studies have revealed that the hyperthyroid patients display high anxiety and less weak executive functions ${ }^{7}$. In their studies Yuanet al., indicated that the untreated hyperthyroid patients had a significant lack of stimulation and executive function networks ${ }^{20}$. Again, when hyperthyroid patients were compared with thyroid patients, it was found that there was a significant decrease in attention, concentration, verbal memory and executive function $\mathrm{s}^{21}$. In these studies, the remarkable finding was that in addition to the other dysfunctions on the neural network functions, the decrease in the executive functions was a common feature among hyperthyroid patients. All these studies prove hyperthyroid patients have cognitive dysfunctions. However, Vogel et al., found that there was no difference between patients with hyperthyroid, who stated that they subjectively experienced a cognitive dysfunction, in terms of their neuropsychological test performances and then when the patients were evaluated again after a year of treatment, it was observed that the symptoms significantly disappeared ${ }^{15}$.

In another study, it was found that hyperthyroid formed for a short time with the administration of $250 \mu \mathrm{g} \mathrm{T} 4$ for 8 weeks caused changes in the brain structures of cerebellum with motor-sensory function related to working memory in those with hyperthyroid ${ }^{22}$. This result can be a cause for the prolonged reaction time in hyperthyroid, which we obtained in the present study; on the other hand, Gottlichet al., revealed that following an 8-week $250 \mu \mathrm{g}$ T4 administration, a significant increase took place in resting-state functional magnetic resonance (fMRI), especially in rostral temporal lobe; this result was interpreted as a possible increase in the connections between temporal lobe and cognitive control network ${ }^{23}$. Although the connections between the temporal lobe and cognitive centers increased, the reason for the prolonged reaction time was considered to be a functional insufficiency among these increased connections. In a study conducted with patients with thyrotoxicosis showing no clinical symptom, it was determined that there was no change in the declarative and working memory, and motor learning was better ${ }^{24}$. In this study, however, the patients with hypothyroid were administered with $\mathrm{T} 4$ and thyrotoxicosis was formed. In addition to all this information, it is known that cerebral venous diseases, cerebralaneurism, and the development of subarachnoid hemorrhage have a relationship with thyroid disorders ${ }^{25}$. Again, the studies indicated that myopathy and neuromuscular weakness were observed among those with hyperthyroid ${ }^{26,27}$. It was considered that as a result of these holistic effects of thyroid hormones on the nervous system, there was a prolonged reaction time of those with hyperthyroid.

The previous study showed that there was a significant increase in audio-visual reaction time in hypothyroid as well as hyperthyroid patients and auditory reaction time decreased significantly after treatment ${ }^{28}$. In 
another study, either in hypothyroidism or in hyperthyroidism the reaction time was considerably prolonged ${ }^{29}$. The findings from these studies support the findings of our hyperthyroid patients prolonged reaction time. In conclusion, thyroid hormone is essential for the normal functioning of auditory mechanisms. Consequently, hyperthyroid patients had prolonged perception time and a significant decrease on attention and concentration. They can result in prolonged reaction time despite lack of impaired motor functions.

\section{Acknowledgements}

This study was supported by TUBITAK (project number: 108S249)

\section{References}

1. Schroeder AC, Privalsky ML. Thyroid Hormones, T3 and T4, in the Brain. Front Endocrinol (Lausanne)2014;40(5):1-6.

2. Lillevang-Johansen M, Petersen I, Christensen $\mathrm{K}$, et al. Is previous hyperthyroidism associated with long-term cognitive dysfunction? A twin study. Clin Endocrinol (Oxf)2014;80(2):290-295.

3. Cho MK. Thyroid dysfunction and subfertility. Clin Exp Reprod Med 2015;42(4):131-5.

4. Ritchie M, Yeap BB. Thyroid hormone: Influences on mood and cognition in adults. Maturitas 2015;81(2):266-75.

5. Beydoun MA, Beydoun HA, Kitner-Triolo MH, et al. Thyroid hormones are associated with cognitive function: moderation by sex, race, and depressive symptoms. J Clin Endocrinol Metab 2013;98(8):3470-81.

6. Kurian MA, Jungbluth $H$. Genetic disorders of thyroid metabolism and brain development. Dev Med Child Neurol 2014;56(7):627-34.

7. Yuan L, Tian Y, Zhang F, et al. Decision-Making in Patients with Hyperthyroidism: A Neuropsychological Study. PLoS One 2015;10: e0129773.

8. Wahlin A, Wahlin TB, Small BJ, et al. Influences of thyroid stimulating hormone on cognitive functioning in very old age. J Gerontol B Psychol Sci Soc Sci 1998;53:234-239.

9. Winkler A, Weimar C, Jockel KH, et al. Thyroid-Stimulating Hormone and Mild Cognitive Impairment: Results of the Heinz Nixdorf Recall Study. J Alzheimers Dis 2015;49(3):797-807.

10. Brent GA. Clinical practice. Graves' disease. N Engl J Med 2008;358(24):2594-2605.

11. Motomura K, Brent GA. Mechanisms of thyroid hormone action. Implications for the clinical manifestation of thyrotoxicosis. Endocrinol Metab Clin N Am 1998;27:1-23.

12. Hu LY, Shen CC, Hu YW, et al. Hyperthyroidism and Risk for Bipolar Disorders: A Nationwide Population-Based Study. PLoS One 2013;8(8): e73057.
13. Oatridge A, Barnard ML, Puri BK, et al. Changes in brain size with treatment in patients with hyper- or hypothy-roidism. AJNR Am J Neuroradiol 2002;23(9):1539-1544.

14. Hogervorst E, Huppert F, Matthews FE, et al. Thyroid function andcognitive decline in the MRC Cognitive Function and Ageing Study. Psychoneuroendocrinol 2008;33(7):1013-1022.

15. Vogel A, Elberling TV, Hørding M, et al. Affective symptoms and cognitive functions in the acute phase of Graves' thyrotoxicosis. Psychoneuroendocrinol 2007;32(1):36-43.

16. Wijsman LW, de Craen AJ, Trompet S, et al. Subclinical Thyroid Dysfunction and Cognitive Decline in Old Age. PLoS One 2013;8(3): e59199.

17. Smith CD, Grondin R, LeMaster W, et al. Thyroid Reversible cognitive, motor, and driving impairments in severe hypothyroidism. Thyroid 2015;25(1):28-36.

18. Ascioglu M, Dolu N, Golgeli A, et al. Effects of cigarette smoking on cognitive processing. Int J Neurosci 2004;114(3):381-90.

19. Moncayo R, Ortner K. Multifactorial determinants of cognition - Thyroid function is not the only one. BBA Clin 2015;3:289-98.

20. Yuan L, Tian Y, Zhang F, et al. Impairment of attention networks in patients with untreated hyperthyroidism. Neurosci Lett 2014;574:26-30.

21. Yudiarto FL, Muliadi L, Moeljanto D, et al. Neuropsychological findings in hyperthyroid patients. Acta Med Indones 2006;38(1):6-10.

22. Gobel A, Heldmann M, Gottlich M, et al. Effect of Experimental Thyrotoxicosis on Brain Gray Matter: A Voxel-Based Morphometry Study. Eur Thyroid J 2015;1:113-8.

23. Gottlich M, Heldmann M, Gobel A, et al. Experimentally induced thyrotoxicosis leads to increased connectivity in temporal lobe structures: a resting state fMRI study. Psychoneuroendocrinol 2015;56:100-9.

24. Samuels MH, Schuff KG, Carlson NE, et al. Health status, mood, and cognition in experimentally induced subclinical thyrotoxicosis. J Clin Endocrinol Metab 2008;93(5):1730-6.

25. Squizzato A, Gerdes VEA, Brandjes DPM, et al. Thyroid Diseases and Cerebrovascular Diseases. Stroke 2005;36(10):2302-2310.

26. Yin J, Zhu J, Huang D, et al. Unilateral symptomatic intracranial arterial stenosis and myopathy in an adolescent with Graves disease: a case report of an high-resolution magnetic resonance imaging study. J Stroke Cerebrovasc Dis 2015;24(1): e49-52.

27. Munir A. Thyrotoxic periodic paralysis: an endocrine cause of paraparesis. J Coll Physicians Surg Pak 2014;2:99-100.

28. Shah SH, Nahar PS. Reaction time in hypothyroid and hyperthyroid patients before and after drug treatment. IOSR J Pharmacy 2012;2(2):218-221.

29. Jonderko G, Straszecka J, Marcisz C, et al. Influence of treating hypothyroidism and hyperthyroidism upon psychical reaction time. Pol Arch Med Wewn 1992;88(5):295-301. 